\title{
A vízjogi szabályozási csomópontok továbbfejlesztésének lehetőségei
}

$$
\text { vízjog - vízvédelem - vízgazdálkodás - vízszolgáltatások - vízhez való jog }
$$

Jelen tanulmány egy nagyobb, a vizek jogi szabályozását elemző kutatás részeként született. Az átfogó kutatás célja a vizekre (elsődlegesen édesvizekre) vonatkozó szerteágazó joganyag egységes szempontok mellett történő elemzése és fejlesztése, alapvetően a magyar társadalom számára kihívást jelentő problémakörökre koncentráltan. Ennek során meghatározásra kerültek bizonyos szabályozási csomópontok, amelyek körét a publikálásunk idején sem tekintettük, és jelenleg sem tekintjük lezártnak, kizárólagosnak vagy egymástól elzártnak. A szabályozási csomópontok között korábban ${ }^{1}$ a következőket nevesítettük: a) a víz mint a tulajdonjog tárgya, b) a víz mint környezeti elem és mint természeti erőforrás, c) a víz mint kereskedelmi ügyletek tárgya, d) a vízhez való jog mint emberi jog, e) a vízgyüjtő terület mint jogintézmények szervezési alapja, $f$ ) a víz mint káresemény, $g$ ) a víz mint élelmiszer. A célunk, ahogyan korábban is, hogy e jogi szabályozási csomópontok jövőbeni fejlesztése immáron egymásra tekintettel történjen meg.

E tanulmányunkban a korábbi kutatásainkban jelzett szabályozási csomópontoktól némileg eltérünk. Tesszük ezt azért, mivel azt gondoljuk, hogy ezen új rendszer talán jobban szolgálja az integratív szemlélet érvényre juttatását, vagyis - jelen esetben -a rendszerezést. Ennek során néhány korábbi szabályozási csomópont összevonásra került, másoknál bizonyos részek kerültek cserére, és volt olyan is, ahol a szabályozási csomópont teljesen új elemekkel bővült. A szabályozási csomópontok újragondolása mindemellett jó alkalmat teremtett arra is, hogy - amelyeknél kutatásaink ezt lehetővé tették - új kutatási eredményeinket is közöljük. Korábbi munkáink kapcsán mások, például Bujdos Ágnes², felhívták a figyelmünket arra, hogy szükségesnek tartják az egyes szabályozási csomópontok közötti kapcsolat nevesítését is. Ez eredetileg jelen munkánknál is cél volt, azonban hamar egyértelművé vált, hogy jelen tanulmány keretei e cél teljesítését nem teszik lehetővé, így e munka a szabályozási csomópontok rendszerezésének újraszabására és - ahol erre lehetőség volt - az új tudományos eredmények bemutatására korlátozódott. Jelen tanulmány szabályozási csomópontjai kapcsán ugyanakkor most is hangsúlyozni kívánjuk, hogy

* Dr. Szilágyi János Ede egyetemi docens, Miskolci Egyetem ÁJK Agrár- és Munkajogi Tanszék, civdrede@ uni-miskolc.hu. Jelen tanulmány a Bolyai János Kutatási Ösztöndíj támogatásával készült.

1 SzILÁGY János Ede: Vízjog - Aktuális kihívások a vizek jogi szabályozásában. Miskolci Egyetem, Miskolc, 2013, 57-62 [a továbbiakban: SzILÁGYI (2013)].

2 Bujdos Ágnes: Vízjog (Aktuális kihívások a vizek jogi szabályozásában). Pro Futuro, 2014/1, 167. 
azok továbbra is inkább csak továbbgondolásra szánt munkahipotézisként kerültek megfogalmazásra, mintsem megdönthetetlen kinyilatkoztatásként.

Mindezekre tekintettel tanulmányunkban elsőként utalást teszünk a szabályozási csomópontok meghatározását lehetővé tevő természettudományi, illetve szakpolitikai alapokra, valamint azon jogintézményekre is, amelyek alkalmasak vagy alkalmasak lehetnek az egyes szabályozási csomópontok közötti kapcsolat formálására. Ezt követően kerül sor négy szabályozási csomópont nevesítésére: a) a víz mint a rendelkezési hatalom tárgya, avagy „Kié a víz?”, b) a víz mint környezeti elem, c) a víz mint természeti erőforrás és kereskedelmi ügyletek tárgya és végül $d$ ) a víz mint káresemény, avagy védelem a víztöl.

\section{A vízjogi szabályozási csomópontok viszonyrendszerének kiindulási alapjai}

Nem tekinthető önálló szabályozási csomópontnak, hanem bizonyos értelemben a szabályozási csomópontok meghatározásának előfeltételét képezi a víz mint környezeti, természeti jelenség mibenlétének és törvényszerüségeinek - például a vízkörforgásnak - a meghatározása. E ponton a jogtudománynak különösen törekednie kell az interdiszciplináris, vagyis a tudományközi módszer alkalmazására, bevonva ezáltal a társadalom-, természet- és mérnöki tudományok legkülönbözőbb területeit. $\mathrm{Az}$ egyes tudományterületek közötti kapcsolatok kialakítását immáron számos tudományközi együttmüködés, program és stratégia segíti; sőt a számos kezdeményezés okán immáron az jelent nehézséget, hogy valamiképpen eligazodjunk ezek tömegében. ${ }^{3}$

A joganyagra kitérve megállapítható, hogy jelentős számban találkozhatunk olyan jogintézményekkel, amelyek a víz sajátos fizikai, környezeti adottságaira, a vízkörforgás törvényszerüségeire, a felszíni és felszín alatti vízgyűjtő területek sokszínűségére reagálva igyekeznek rendezni az emberek társadalmi viszonyrendszerét. Ilyen jogintézmények kialakítását és müködtetését tűzte ki célul az Európai Unió Víz-keretirányelve ${ }^{4}$ (a továbbiakban: VKI) ${ }^{5}$. Habár teljesen más megfontolásból, de szintén

${ }^{3}$ Egyfajta szelekciós kísérletként lásd SzILÁGYI (2013): i. m., 25-57; SZILÁGYI János Ede: Az EU és Magyarország vízstratégiája. Publicationes Universitatis Miskolcinensis. Sectio Juridica et Politica (PUMSJP), Tomus XXXI, 2013, 475-497.

4 A vízpolitika terén a közösségi fellépés kereteinek meghatározásáról szóló 2000/60/EK parlamenti és tanácsi irányelv (2000. október 23.). A VKI végrehajtására Magyarországon megalkotásra került a Vízgyűjtögazdálkodási Terv (VGT), amelyet - az eredeti 1127/2010. Korm. határozat 6/2011. AB határozattal történő megsemmisítését követően - az 1042/2012. Korm. határozattal hirdettek ki. Jelenleg zajlik a VGT2 készítése figyelemmel az EU Bizottság VGT kapcsán kifejtett észrevételeire, illetve az EU 2014 és 2020 közötti költségvetési időszakára (és legfőképpen annak uniós támogatásaira); lásd minderröl az 1940/2013. Korm. határozatot (a Kvassay Jenő Terv elkészítéséröl és a Vízgyüjtö-gazdálkodási Terv felülvizsgálatáról), az 1121/2014. Korm. határozatot (a 2014-2020 közötti uniós források felhasználásáról).

5 Figyelemmel egyébiránt a VKI végrehajtásának nehézségeire a kizárólag energiahasznosítás céljából kitermelt termálvíz felhasználását segítő egyes kérdésekről szóló 2053/2013. (XII. 31.) Korm. határozattal a Kormány döntött arról, hogy Magyarország a vízgyüjtö-gazdálkodási tervben a vizek jó állapot elérésének eredeti, vagyis 2015. évi határideje alól 2027-ig mentességet kezdeményezzen. A mentesség terjedelme a 
európai uniós kezdeményezésre született, és egy átfogó szemléletű megközelítését adja a vízjogi szabályozásnak a létfontosságú rendszerekről szóló 2012. évi CLXVI. törvény is. Ez a létfontosságú rendszerelemek védelme érdekében - alapvetően a terrorizmus elleni harc jegyében - veszi számba (más létfontosságú ágazatok mellett) a vízzel kapcsolatos „létfontosságú rendszerelemeket”. ${ }^{6}$ A víz esetében közvetlenül ilyenként kerülnek megjelölésre a vízi közlekedés, az ivóvíz-szolgáltatás, a felszíni és felszín alatti vizek minőségének ellenőrzése, a szennyvízelvezetés és -tisztítás, a vízbázisok védelme, és végül az árvízi védmüvek és gátak. ${ }^{7}$

Egy állam esetében kétségtelenül az alkotmány is betölthet ilyen, szabályozási csomópontok közötti szervező, koordináló szerepet. Meglátásunk szerint a magyar Alaptörvény e vonatkozásban meglehetősen előremutató alkotmánynak tekinthető. Hasonlóképpen segíti az integratív szemlélet érvényesülését az a helyzet, amikor egy állam a vízgazdálkodással és vízvédelemmel kapcsolatos közigazgatási rendszerét a vízgyüjtő területek sajátosságaira figyelemmel szervezi meg. Utóbbihoz szorosan kapcsolódik a vizek kártételei elleni védekezés költségeinek megoszlását szolgáló jogintézmények kialakítása; Magyarországon például e körbe sorolható a vízi társulatok szabályozása.

\section{A víz mint a rendelkezési hatalom tárgya, avagy „Kié a víz?”}

Jelen részben alapvetően a folyékony halmazállapotú természetes édesvizek (felszíni, illetve felszín alatti víz, csapadékvíz), ezek természetes és mesterséges közegének (meder, sziget, csatorna, tározó), valamint az ezek hasznosításához közvetlenül kapcsolódó tárgyak (árvízvédelmi védvonalak, vízi létesítmények, vízi közmüvek) feletti rendelkezési hatalom, köztük a tulajdoni jogok kérdéseivel foglalkozunk. A már kitermelt vízhez kötődő jogi problémákra jelen tanulmánynak a vízzel mint kereskedelmi ügyletek tárgyával foglalkozó részében térünk ki részleteiben.

Az e részben nevesített vízjogi szabályozási csomópont korábbi kutatásainkban a „víz mint tulajdonjog tárgya” elnevezést kapta. E szabályozási tárgy kapcsán azonban érdemes lehet feltenni egy, a klasszikus tulajdoni kategórián ${ }^{8}$ túlmutató kérdést:

kormányhatározat szövegéből nem derül ki pontosan; nevezetesen, hogy az csak a termálvizekre vonatkozik vagy általánosságban, minden víz vonatkozásában. Megjegyzendő, hogy korábban már több tagállam is jelezte (Hollandia, Egyesült Királyság), hogy tekintettel a várható költségek nagyságára, a 2015-ös határidő tarthatatlan számára, és - élve az irányelv nyújtotta lehetőséggel - 2027-ig nyújtja ki a cél elérésének tervezett dátumát; Krämer, Ludwig (ed.): EU Environmental Law. Sweet \& Maxwell-Thomson Reuters, London, 2012, 256.

6 Az ilyen elemek legfontosabb ismérve, hogy az „elengedhetetlen a létfontosságú társadalmi feladatok ellátásához - így különösen az egészségügyhöz, a lakosság személy- és vagyonbiztonságához, a gazdasági és szociális közszolgáltatások biztosításához -, és amelynek kiesése e feladatok folyamatos ellátásának hiánya miatt jelentős következményekkel járna”; 2012. évi CLXVI. tv. 1. § f) pont. A téma részletes elemzéséről lásd SzILÁGYI János Ede: A vízágazat létfontosságú rendszerelemeinek biztonságpolitikai védelme és a magyar vízjog. PUMSJP, Tomus XXXIII, 2015, megjelenés alatt.

7 2012. évi CLXVI. tv. 1. melléklet 7. pont, 3. melléklet 33-37. pontok.

8 Ebben a témakörben relatíve sok munka született; a magyar vonatkozások tekintetében lásd például: PuMP Judit: Víziközművek a jogértelmezés csapdájában. Magyar Jog, 2008/8, 525-530; jelen tanulmány szerzőjétől lásd SzILÁGYI (2013): i. m., 63-94. 
nevezetesen, hogy kié a víz? A „kié a víz?” kérdéssel ugyanis túlmutathatunk a tulajdoni részjogosítványok teljességét magában foglaló magánjogi kategória, vagyis a tulajdonjog jogintézményén, és e kérdés lehetőséget teremt a víz vonatkozásában további, érintett szereplők érdekeinek megjelenítésére is. A „kié a víz?” kérdés lehetőséget ad arra, hogy mind közjogi (egyfajta szuverenitási), mind pedig magánjogi (tulajdoni) kategóriában, mind pedig a jogi kereteket túllépő intergenerációs (nemzedékek közötti) viszonyrendszerben vizsgáljuk e kérdéskört. Mindezekre tekintettel magunk különösen fontosnak tartanánk az Alaptörvényben ${ }^{9}$ is szereplő, a vizek jogi szabályozását érintő kategóriák közötti kapcsolat vizsgálatát. Így a generációk közötti viszony rendezését (értve ezalatt a jelen, illetve jövő generációk közötti kapcsolatot), a globális, illetve a lokális közösség közötti viszony vizsgálatát (értve ezalatt a nemzetközi jogban ismert emberiség közös öröksége, valamint az Alaptörvényben szereplö nemzet közös öröksége koncepciókat), és végül a nemzeti vagyon kategória alaptörvényi, illetve környezetvédelmi törvényi (Kvt.) koncepciói között húzódó ellentmondások feloldását, de legalábbis nevesítését. A következőkben e viszonyrendszereket vizsgáljuk meg.

a) Az Alaptörvény számos ponton kitér a jövő nemzedékek érdekeinek védelmére. ${ }^{10}$ Az Alaptörvény $P$ ) cikke külön a vízkészletek kapcsán is nevesíti, hogy azok védelme és fenntartása, valamint a jövő nemzedékek számára való megőrzése az állam és mindenki kötelessége. Hasonlóképpen előremutatónak véljük az Alaptörvény 36-37. cikkeit, amelyek - több más mellett - az államadósság maximális mértékét hivatottak meghatározni, és amelyek céljuk alapján értelmezhetők akképpen is, hogy a jelen generációk egy esetleges hitelcsapdával ne lehetetlenítsék el pénzügyileg az utánuk következő generációkat. Ezen értelmezést támasztja alá az Alaptörvény 36. cikkhez adott indoklása is, amely szerint az Alaptörvény „a jövő nemzedékek helyzetéért viselt felelősséget tekintetbe véve” írja elő az államadósság növekedését gátló szabályokat; hasonlóképpen indokolja a jogalkotó a 37. cikket is, vagyis hogy az Alaptörvény „annak érdekében, hogy az aktuális szükségletek vagy érdekek túlzott elötérbe helyezése ne róhasson elviselhetetlen terhet a jövendő generációkra" vezeti be a szigorú költségvetési szabályokat. Úgy véljük, hogy mindezek alapján egyér-

9 A víz alaptörvényi rendelkezéseinek elemzéséröl lásd különösen FodoR László: A víz az Alaptörvény környezeti értékrendjében. PUMSJP, Tomus XXXI, 2013, 334-345.

10 Lásd az Alaptörvény Nemzeti Hitvallását, valamint 30. és 38. cikkeit. A kapcsolódó koncepció (fenntartható fejlődés) elemzéséről lásd példaként a magyar jogirodalomból: Bándi Gyula (szerk.): A fenntartható fejlődés koncepciójának megjelenése a nemzetközi és európai jogban, valamint az EU-tagállamok gyakorlatában. NFFT Műhelytanulmányok 6., Nemzeti Fenntartható Fejlödési Tanács, Budapest, 2011, 6-11, 61-76; BÁNDI Gyula: A fenntartható fejlődés jogáról. Pro Futuro, 2013/1, 11-30; BÁnYAl Orsolya: Energiajog az ökológiai fenntarthatóság szolgálatában. DELA, Debrecen, 2014, 16-55; FoDoR László: A természeti tárgyak helye és szerepe az új alkotmányban. In: Drinóczi Tímea-Jakab András (szerk.): Alkotmányozás Magyarországon 2010-2011. PPKE JÁK-PTE ÁJK, Budapest-Pécs, 2012, 9-103; HoRvÁtH Zsuzsanna-PÁnovics Attila: Környezetvédelem és fenntarthatóság az új Alaptörvényben. In: Drinóczi Tímea (szerk.): Magyarország új alkotmányossága. PTE ÁJK, Pécs, 2011, 77-95; PÁnovıcs Attila: A fenntartható fejlődés belső és külső dimenziói az Európai Unióban. Európai Tükör, 2007/12, 120-127; SzABó Marcel: A fenntartható fejlődés: nemzetközi jogi elmélet és szerződéses gyakorlat. In: Raisz Anikó (szerk.): A nemzetközi környezetjog aktuális kihívásai. Miskolci Egyetem, Miskolc, 2012, 161-174. 
telműen megállapítható az a jogalkotói szándék, amely a jövő generációk eladósodását kívánja elkerülni. Az Alaptörvény 36. cikk (4) bekezdése az államadósság maximumát a teljes hazai össztermék ${ }^{11}$ felében határozza meg. E ponton érdemes kitérni arra, hogy speciálisan a vizek vonatkozásában is találhatunk olyan kötelező érvényű előírásokat, amelyek a jövő generációk pénzügyi védelmét (is) szolgálják. Nevezetesen, a vízkészletek - egész pontosan a vízszolgáltatások - kapcsán a VKI szerinti költségmegtérülés elvét ${ }^{12}$, amely a magyar jogrendszer részévé is vált, általánosságban a vízgazdálkodásról szóló 1995. évi LVII. törvény (Vgtv.) 15. § (7) bekezdésében, speciálisan pedig például a víziközmü-szolgáltatásról szóló törvényben (Vksztv.). ${ }^{13} \mathrm{~A}$ VKI 9. cikk (1) bekezdése a költségmegtérülés tartalma kapcsán a következőket állapítja meg: a „tagállamok figyelembe veszik a vízszolgáltatások megtérülésének elvét, beleértve a környezeti és a vízkészletekkel összefüggö költségeket”. Vagyis a VKI szerinti „teljes gazdasági költségre” kiterjedő költségmegtérülés elve lényegében három költségelemet nevesít: a pénzügyi költségeket és az ún. külső költségeket, amely utóbbi további két elemböl áll, a környezeti költségekből és a készletköltségekből. Meglátásunk szerint a három költségelem közül különösen a külső költségek lehetnek azok, amelyek a jövő generációk (pénzügyi) érdekeinek megtestesítésére is alkalmasak. ${ }^{14}$ Kétségtelen tény ugyanakkor, hogy pont a külső költségeket alkotó két költségelem meghatározása több vonatkozásban is bizonytalan, ${ }^{15}$ és pontos kimunkálásuk még nem tekinthető lezártnak.

b) Az Alaptörvény $P$ ) cikke a vízkészleteket a nemzet közös örökségeként definiálja. ${ }^{16} \mathrm{E}$ leginkább államtudományi, közjogi megközelítésben értelmezhető kategóriát magunk részéről - hasonlóan más szerzőkhöz - bizonyos értelemben az emberiség közös öröksége kategóriával gondoljuk szembeállíthatónak. Ennek kapcsán érdemes utalni azon, a nemzetközi jogi irodalomból ismert törekvésekre, amelyek az emberiség közös örökségére hivatkozással próbálnak meg kivonni bizonyos felszín

11 Az Alaptörvény 37. cikkének (6) bekezdése pedig, e szabályt kiegészítve, azt rendeli, hogy az államadósság és a teljes hazai össztermék számítási módját törvényben (a Magyarország gazdasági stabilitásáról szóló 2011. évi CXCIV. törvényt; Gst.) határozzák meg. Mindezek kapcsán - némi kitérőként - fontosnak tartjuk megjegyezni, hogy mind az Alaptörvény indoklása, mind pedig a Gst. a teljes hazai össztermék kifejezés helyett a - közgazdaságilag pontosabbnak tünő - bruttó hazai termék (vagyis angol rövidítésével: GDP) kifejezést alkalmazza, ezáltal a gazdasági fejlődés általános paramétereként használt GDP kategóriát megtéve az államadósság túlzott mértéke elleni küzdelem viszonyszámának is.

12 Részletes értelmezéséről lásd SzILÁGY János Ede: A magyar víziközmű-szolgáltatások és a Víz-keretirányelv költségmegtérülésének elve. Miskolci Jogi Szemle, 2014/1, 73-83, 85-88 [a továbbiakban: SzILÁGYI (2014)]; CsIBI Andrea-SzILÁGY János Ede: A költségmegtérülés elvének érvényesülése a vízszolgáltatások körében. PUMSJP, Tomus XXXII, 2014, 375-384.

13 2011. évi CCIX. tv. 1. § (1) bek. h) pont.

14 Részletes elemzésükröl lásd SzILÁGYI (2014): i. m., 78-82, 85-88.

15 Részletes elemzésükröl lásd SzILÁGYI (2014): i. m., 78-82.

16 A víz örökségként történő meghatározásának vannak uniós jogi alapjai is, lásd VKI preambulum (1) pont („a víz nem szokásos kereskedelmi termék, hanem örökség”); valamint a C-525/12. sz., Európai Bizottság kontra Németországi Szövetségi Köztársaság ügy 2014. május 22-i fötanácsnoki indítványának 65. pontja („a víz különös védelmet igénylő örökségünknek minősül”, ECLI:EU:C:2014:449). Egyik hivatkozott forrás sem részletezi ugyanakkor, hogy kit ért örökösnek e viszonyrendszerben. 
alatti vizeket az állami szuverenitás koncepciója alól. ${ }^{17}$ Úgy gondoljuk, hogy e jogirodalomban ismert vitában a nemzet közös örökségének vizekre is kiterjedő kategóriája egyfajta állásfoglalásként értékelhető az állami szuverenitás mellett. Kétségtelen tény ugyanakkor, hogy számos felszíni és felszín alatti vízadónk határral osztott, erre tekintettel pedig a nemzet közös örökségének - egyébiránt részleteiben nem meghatározott - kategóriája, annak abszolút formában történő értelmezése esetén, konfliktusok forrása lehet a jövőben a szomszédos országokkal. Meglátásunk szerint tehát a határral osztott vízadók tekintetében a nemzet közös öröksége kategória csak megkötésekkel fogadható el, a határvizek (amely kategória egyébiránt szintén több értelemben is definiálható) vonatkozásában a más népekkel való együttmüködésre törekvés kötöttségével - amely elvárás meghatározásra is került az Alaptörvény Q) cikkében, ráadásul és többek között, éppen az „emberiség fenntartható fejlődése érdekében" kitétellel - korlátozva tartjuk helyesnek értelmezni.

c) Fontos kiemelni, hogy a fentebb taglalt nemzet közös öröksége kategória nem esik egybe az Alaptörvény egy másik kategóriájával, nevezetesen a nemzeti vagyonnal, amely pedig - nem mellesleg - nem egyezik a környezet védelmének általános szabályairól szóló 1995. évi LIII. törvény (Kvt.) preambulumában található ugyanilyen elnevezésủ kategóriával. Míg az Alaptörvény nemzeti vagyon kategóriája - és az ez alapján elfogadott sarkalatos törvény (Nvtv. ${ }^{18}$ ) - az állami és önkormányzati tulajdont, illetve vagyont foglalja magában, addig - egy elfogadottnak tekinthető jogirodalmi értelmezés szerint ${ }^{19}-a$ Kvt. nemzeti vagyon kategóriája egy szembehelyezkedésnek tekinthető azon teóriával, amely szerint a környezeti értékek uratlan dolgok lennének. Mindemellett pedig a Kvt. nemzeti vagyon kategóriája nem azonositható egyik tulajdoni formával sem (például az államival), hanem magában foglalja az ország szempontjából meghatározó értékeket, függetlenül attól, hogy azok kinek a tulajdonában állnak. Mindezen lehatárolásnak abból a szempontból van jelentősége, hogy a vizek mindkét (az Alaptörvény - Nvtv., mind pedig a Kvt.) nemzeti vagyon kategóriája által érintettek, ebböl kifolyólag viszont alapvető fontosságú a konkrét ügyben az érintett kategória tisztázása.

\section{A víz mint környezeti elem}

A víz mint környezeti elem elnevezésủ szabályozási csomópont a vízre akként tekint, mint amely része egy nagy rendszernek, a környezetnek, és amely önmagában emiatt is (közvetett) jogi szabályozási tárggyá válhat, válik. Jelen szabályozási csomópont ebböl kifolyólag szoros összefüggésben van a környezetjoggal, és ezért

17 A vita részleteiröl lásd RAISz Anikó: A felszín alatti vizek határon átnyúló szennyezésére vonatkozó nemzetközi szabályozás. PUMSJP, Tomus XXX/2, 2012, 379-382; lásd még RAIsz Anikó: Water as the Nation's Common Heritage in the Frame of the Common Heritage of Mankind. In: Greksza Veronika-Szabó Marcel (eds.): Right to Water and the Protection of Fundamental Rights in Hungary. University of Pécs, Pécs, 2013, 84-96.

18 Lásd a nemzeti vagyonról szóló 2011. évi CXCVI. tv.

19 BÁNDI Gyula: Környezetjog. Szent István Társulat, Budapest, 2011, 24-25 [a továbbiakban: BÁNDI (2011)]. 
igazak rá azon sajátosságok, amelyek a környezetjogra is; így például az, hogy lényegében a jogrendszer minden más területével szoros kapcsolata van. Amiként a Kvt. általános indoklása megfogalmazta: „A környezetvédelmi szabályozás megújítása elsődlegesen a környezetbarát jogrendszer fogalmával jellemezhetö...[;] nem képzelhetö el környezetvédelmi jogi szabályozás önmagában... [;] [n]em létezhet párhuzamosan egymás mellett a környezetvédelmi jogterület és a rajta kívüli minden más jogterület... [;] semmilyen szabályozás sem lehet megalapozott napjainkban környezetvédelmi érintettség nélkül..."

A környezetjog minden (nemzetközi, európai uniós, nemzeti) szabályozási szintje komoly vízjogi relevanciával bír. A környezetjog általános része lényegében minden szempontból, a környezetjog különös része pedig számos vonatkozásban (különösen klímavédelem, természetvédelem, földvédelem) kapcsolódik a vizekhez. A víz mint környezeti elem jogi szabályozása kapcsán számos problémakör érdemelne kiemelt figyelmet, jelen tanulmányban azonban - a teljesség igénye nélkül - csupán háromra utalunk.

a) A víz mennyiségi és minőségi aspektusai. A VKI egyik fontos sajátossága, hogy elsődlegesen a vizek minőségi vonatkozásait rendezi, míg a mennyiségi gazdálkodás aspektusait pusztán csak kiegészítő jelleggel taglalja. Ez a sajátosság egyébiránt a VKI „jogalapját tükrözi, mivel azt a korábbi együttdöntési eljárásra vonatkozó EK 175. cikk (jelenleg EUMSZ 192. cikk) alapján fogadták el. Ugyanakkor e tekintetben meg kell jegyezni, hogy az EK 175. cikk (2) bekezdéséből eredően a menynyiségi vízkészlet-gazdálkodást, illetve az e készletek rendelkezésre állását akár közvetlenül, akár közvetve befolyásoló intézkedések problematikája a jogalkotási eljárás során egyhangú döntéshozatalt követelt meg."20 Márpedig ezen egyhangú döntéshozatalra a tagállamok közötti érdekellentétek miatt nem kerülhetett volna sor.

A magyar nemzeti elöírásokra áttérve megállapítható, hogy a vizek védelmét több törvény ${ }^{21}$ is érinti expressis verbis, amely törvények közül, jelentöségüknél fogva különösen a Kvt. és a Vgtv. emelkedik ki. A magyar szakirodalomban elterjedt nézet szerint a magyar vízvédelem esetén is érdemes megkülönböztetni annak két aspektusát. Az egyik a vizek minőségi kérdéseit taglaló ún. minőségi vízvédelem, a másik pedig a vízkészletek mennyiségi aspektusait magában foglaló ún. mennyiségi vízvédelem. Van olyan szerző, aki „általános szabályként”, a víz minőségi védelmének kiindulási jogszabályaként a Kvt.-t, a víz mennyiségi védelmének bázisaként a Vgtv.-t határozza meg. ${ }^{22}$ Ehhez kapcsolódóan létezik olyan értelmezés is, amely szerint egyébiránt a mennyiségi vízvédelem „leegyszerűsítve, általában azonosítható a vízgazdálkodással" ${ }^{23}$ amely kijelentést a Vgtv. fogalomhasználatára tekintettel csak bizonyos megszorításokkal lehet elfogadni, hiszen a Vgtv. vízgazdálkodási

20 A C-525/12. sz., Európai Bizottság kontra Németországi Szövetségi Köztársaság ügy 2014. május 22-i fötanácsnoki indítványának 41. pontja; lásd továbbá az indítvány 40-42., 70-71., 89. pontjait (ECLI:EU:C:2014:449).

21 Lásd például a teljesség igénye nélkül készített vonatkozó felsorolást: SzILÁGYI (2013): i. m., 142-143.

22 MıKLós László: A vízvédelem szabályozása. In: Miklós László (szerk.): A környezetjog alapjai. SZTE ÁJKJATEPress, Szeged, 2011, 75.

23 BÁNDI (2011): i. m., 453. 
fogalmába ${ }^{24}$ nemcsak a víz védelme értendő bele, hanem a víztől való védelem is (értsd: a vízkárelháritás). A Vgtv. egy másik alapkategóriája, a vízhasználat ${ }^{25}$ pedig egyértelmüen utal arra, hogy a Vgtv. hatálya a mennyiségi aspektusokon kívül magában foglalja a minőségit is. A Vgtv. fogalomhasználatában a mennyiségi vízvédelem sokkal inkább a vízkészlet-gazdálkodás ${ }^{26}$ meghatározásával jelölhetö. A legtöbb szerző talán éppen ezért ért egyet abban, hogy számos vízvédelmi jogszabály mind minőségi, mind mennyiségi előírásokat is magában foglal, azaz a vízvédelem két aspektusa az egyes vízvédelmi jogszabályokban nem különül el élesen egymástól. ${ }^{27}$ Ez természetesen legfóképpen annak tudható be, hogy a vízkivételek - vagyis a vizek mennyiségi változása - közvetlenül befolyásolja a vizek minöségét. Mindezt egyébiránt magának a Kvt.-nek a rendelkezései is megerősítik: ${ }^{28}$ ezek szerint a környezeti elemek - mint amilyen a víz ${ }^{29}$ - védelme egyaránt jelenti azok minőségének, mennyiségének és készleteinek a védelmét. ${ }^{30}$ Következésképpen megállapíthatjuk, hogy habár a vízvédelem mennyiségi és minőségi oldala közötti különbségtételnek van létjogosultsága, a Kvt. és Vgtv. között nem lehet a szerint különbséget tenni, hogy a Kvt. a vizek minőségi, míg a Vgtv. a vizek mennyiségi védelmére lenne inkább hivatott. Meglátásunk szerint a Kvt. egy szélesebb rendszerben közelíti meg a vizeket (ráadásul a pusztán védelmi szemléletet meghaladó, tágabb magatartásrendszerben), illetve az azokat érintő környezethasználatokat ${ }^{31}$, a Vgtv. pedig - figyelemmel a Kvt. és kapcsolódó más környezetvédelmi és természetvédelmi jogszabályok elöírásaira ${ }^{32}$ - egy szükebb vízkárelhárítás ${ }^{33}$ és - a leginkább a vizek természeti erőforráskénti megközelítéséhez kötődő - vízhasznosítási viszonyrendszerben teszi azt.

24 „Vizgazdálkodás: a vizek hasznosítása, hasznositási lehetőségeinek megőrzése, a vizek kártételei elleni védelem és védekezés (vízkárelhárítás).”Vgtv. 1. sz. melléklet 22. pont; lásd továbbá a Vgtv. tárgyi hatályról rendelkező $1 . \S(1)$ bekezdését.

25 „Vízhasználat: az a tevékenység, amelynek következménye a víz lefolyási, áramlási viszonyainak, mennyiségének, minőségének, továbbá a medrének, partjának a víz hasznositása érdekében való befolyásolása." Vgtv. 1. sz. melléklet 23. pont; lásd továbbá a Vgtv. tárgyi hatályról rendelkező 1. § (1) bekezdését. Vö. a VKI 2. cikk 39. pontjában meghatározott vízhasználat fogalmával, amely a VKI alapvetően minőségi megközelítése miatt más terjedelemmel bír; lásd még erről C-525/12. sz., Európai Bizottság kontra Németországi Szövetségi Köztársaság ügy 2014. május 22-i fötanácsnoki indítványának 77-78., valamint 40-42., 70-71. pontjait (ECLI:EU:C:2014:449).

26 „Vízkészlet-gazdálkodás: azoknak a tevékenységeknek az összessége, amelyeknek célja a vizek használatára irányuló igények kielégítése oly módon, hogy ennek következtében a vizek állapotában visszafordithatatlan változás ne következzék be és a vízkészlethez való hozzáférés lehetősége ne csökkenjen" - Vgtv. 1. sz. melléklet 29. pont.

27 Lásd például BÁNDI (2011): i. m., 454; CsÁK Csilla: Környezetjog. Novotni Kiadó, Miskolc, 2008, 102.

28 Kvt. 13. § (2) bek.

29 „Környezeti elem: a föld, a levegő, a víz, az élővilág, valamint az ember által létrehozott épített (mesterséges) környezet, továbbá ezek összetevői”-Kvt. 4. §1. pont.

30 Hasonlóképpen rendelkezik a Kvt. 18. § (1) bek. és 21. § (1) bek.

31 „Környezethasználat: a környezetnek vagy valamely elemének igénybevételével, illetőleg terhelésével járó tevékenység" - Kvt. 4. § 9. pont.

32 Lásd erről a Vgtv. preambulumát.

33 A fogalmáról lásd a Vgtv. 1. sz. melléklet 30. pontját. 
b) Felszín alatti és felszíni vizek integrált védelme és állapotuk fejlesztése. Úgy gondoljuk, hogy nem igényel különösebb igazolást, ha megállapítjuk, hogy a felszín alatti vízadók és a felszíni vízadók védelme, a velük való gazdálkodás, valamint a rájuk vonatkozó jogi szabályozás jelentős eltérést mutat. A jogi szabályozás kapcsán röviden arra érdemes utalni, hogy bizonyos pontokon kívánatos lenne a felszín alatti vizek jogi szabályozását felzárkóztatni a felszíni vizek esetén létező szabályozásivédelmi szinthez, a kettő közötti (bizonyos értelemben hátrányos) megkülönböztetést megszüntetni, és a kettőt még nagyobb fokú rendszerszemlélettel kezelni. A felvetettekkel kapcsolatban szorosan összefügg az alább részletezendő problémakör is, amely jó példa a felszíni és felszín alatti vízadók eltérő védelmi szintű szabályozására.

c) A határral osztott felszíni és felszín alatti vízadók. Mivel Magyarország vízadóinak jelentős része határral osztott, ezért kutatásunknak különösen fontos kérdése az, hogy mennyire lehet hatékony a magyar vízvédelmi szabályozás az uniós és nemzetközi jog nem létező, avagy létező, de nem, illetve nehezen végrehajtható szabályainak keretében. Néhány sorral feljebb éppen annak kapcsán fogalmaztuk meg kritikai észrevételeinket, hogy a jelen generációk a jövő generációk terhére vállalnak fel terheket. Ugyanígy bírálandó azonban az is, amikor például a felvízi országok az alvízi országokra hárítják a környezeti terheket. Ne csak a piac és annak védelme legyen közös, de a környezetünk és annak védelme is! A VKI és a kapcsolódó jogi előirások egyik legnagyobb hiányossága (a számtalan mentesülési lehetőség mellett ${ }^{34}$ ) a vizek határon átnyúló mennyiségi és minőségi kérdéseinek a nem megfelelő rendezése. A problémakör egyik fontos eleme a felmerülő, rendkívül komplex felelősségi kérdések vizsgálata is.

\section{A víz mint természeti eröforrás és kereskedelmi ügyletek tárgya: áru és szolgáltatás}

Az előző két szabályozási csomópontban számos esetben (ha nem is kizárólagosan) a vizek emberi kitermelés előtti állapotával és a mindezekhez kötődő társadalmi viszonyokkal foglalkoztunk. Jelen szabályozási csomópont azonban már egyértelműen a víz kitermeléséről, emberi felhasználhatóságáról szól. A szabályozási csomópont alábbi elemzése során törekedtünk rá - még ha ez nem is volt minden vonatkozásban lehetséges -, hogy az általánostól a speciális felé haladva kerüljenek bemutatásra a szabályozás egyes elemei. Ezen logikai vezérfonal mentén igyekszünk bemutatni, hogy a víz mint természeti eröforrás, miként válhat a kereskedelmi ügyletek tárgyává, áruként, illetve szolgáltatásként. Utóbbi kategórián belül külön jelentőséget tulajdonítunk a közvetlen emberi felhasználásnak, kitérve a vízhez való jogra is.

${ }^{34}$ Lásd az EU Bírósága C-525/12. sz., Európai Bizottság kontra Németországi Szövetségi Köztársaság ügyben 2014. szeptember 11-én hozott ítéletét (ECLI:EU:C:2014:2202). 
a) A víz mint környezeti elem elnevezésű szabályozási csomóponthoz képest a víz természeti erőforrásként történő definiálása már egyfajta szűkítést foglal magában. Az Alaptörvény maga is több helyen tartalmaz elöírásokat a természeti eröforrások vonatkozásában, annak tartalmát illetően azonban egyedül a $\mathrm{P}$ ) cikkben találhatunk némi fogódzót. Az Alaptörvény $P$ ) cikke a természeti erőforrásoknak ugyanis egy példálózó felsorolását adja, ekként nevesítve a termőföld és az erdők mellett a vízkészletet is. Az Alaptörvényhez képest átfogóbb és részletesebb kategóriát tartalmaz a Kvt., amely (4. § 3 . pont) természeti erőforrásként definiálja $a-$ mesterséges környezet kivételével - társadalmi szükségletek kielégitésére felhasználható környezeti elemeket (így: a földet, levegöt, vizet, élővilágot) vagy azok egyes összetevőit. A Kvt. tehát egy az Alaptörvényhez képest teljesebb felsorolást ad a természeti eröforrások körét illetően, egyúttal meghatározza a környezeti elem és a természeti eröforrás közötti differentia specificát, nevezetesen a társadalmi szükségletek kielégítésére való felhasználhatóságot. Utóbbi sajátosság - habár meglehetősen tágan értelmezhető, ráadásul időben is változó kategóriát takar - mindazonáltal a víz mint környezeti elem körét leszükíti azon vizekre, amelyek esetén a társadalmi felhasználhatóság lehetősége egyáltalán megjelenhet. A vizekre vonatkozó jogi szabályozást tekintve, talán ez a szabályozási tárgy az, amelyet a Vgtv. ${ }^{35}$ vízkészlet-gazdálkodási kategóriája leginkább lefed. A magunk részérö| ${ }^{36}$ egyébiránt - legtágabb értelemben - a víz mint természeti erőforrás szabályozási tárgy alá soroljuk azt az esetet is, amikor egy ember a saját személyes szükségletei kielégitésére vételez vizet egy természetes vízadóból (például megtölti kulacsát a forrásvízből).

A vizek vonatkozásában e ponton érdemes végiggondolni azt is, hogy a vizek milyen specialitásokkal is bírnak a természeti erőforrások között. Míg a Kvt. ${ }^{37}$ a vizet mint korlátozottan előforduló (természeti) erőforrást (valamint alapvető életfeltételt) határozza meg, addig a $V K I^{38}$ a felszíni és a felszín alatti vizeket elvben megújuló természeti erőforrásként definiálja. A vízkörforgás sajátosságaira tekintettel - minthogy a vízkörforgás más aspektusait emelik ki -, mindkettővel egyet lehet érteni (vagy éppen mindkettőt lehet vitatni).

b) A természeti erőforrás kategórián belül a jogi szabályozási helyzetét illetően speciális helyet foglal el azon vizek köre, amelyek kereskedelmi ügyletek tárgyaivá válnak (utóbbi kör kapcsán természetesen felhívjuk a figyelmet a VKI preambulumában található figyelmeztetésre: nevezetesen, hogy „a víz nem szokásos kereskedelmi termék"). Amíg a természeti erőforrás kategória esetén a társadalmi szükségletek kielégítésének puszta lehetőségét fogalmazza meg a jogalkotó, addig a kereskedelmi ügyletek tárgyát képező áru, illetve szolgáltatás kategóriák már jelentősebb

\footnotetext{
35 A Vgtv. preambuluma a törvény megalkotásának indokaként is a vizek hasznosítását, hasznosítási lehetőségeinek megőrzését fogalmazza meg (hozzátéve ugyanakkor a vizek kártételeinek elhárításával összefüggő emberi magatartásokat is).

36 Vö. a C-525/12. sz., Európai Bizottság kontra Németországi Szövetségi Köztársaság ügy 2014. május 22-i főtanácsnoki indítványának 32. pontjával (ECLI:EU:C:2014:449).

37 Kvt. 19. § (1) bek.

38 A VKI indokolásának (28) pontja.
} 
szükítést takarnak. ${ }^{39}$ Korábbi kutatásainkban egyébiránt foglalkoztunk azzal is, hogy a két kereskedelmi kategória miként határolható el egymástól a vizek vonatkozásában. ${ }^{40}$

A víz mint kereskedelmi ügyletek tárgya kapcsán fontos problémakört foglal magában az ún. „virtuális vízkereskedelem” témaköre. ${ }^{41} \mathrm{~A}$ vízkereskedelem mint ún. „virtuális víz” vagy „beágyazott víz” kereskedelme globális ügy. A virtuális, illetve beágyazott víz kifejezés azon víz mennyiségére utal, amelyet egy adott áru vagy szolgáltatás elóállítására felhasználtak (hasonlóképpen, mint a vízlábnyom ${ }^{42}$ ). Ezen eljárás alapján az egyes államok a víz kereskedelmében termékeken keresztül vesznek részt, és nem a víznek magának a fizikai szállításán keresztül, amely egyébiránt egy bonyolult és költséges gyakorlat lenne. E transzformációs eljárás eredményeként több milliárd tonna élelmiszerrel és egyéb termékkel kereskednek világszerte, és elmondható, hogy számos vízben szegény ország (például a Közel-Keleten) a virtuális víz nettó importőrévé vált. A virtuális vízkereskedelem kapcsán a következő körülményekre hívja fel a figyelmet az ENSZ. ${ }^{43}$ (i) Bár a jelenség kapcsán felmérések bizonyítják, hogy sok esetben állapítható meg vízmegtakarítás, ugyanakkor az hangsúlyozandó, hogy a virtuális víz kereskedelmével, tehát pusztán kereskedelmi kérdésként nem garantálható a fenntartható vízgazdálkodás. Mivel a virtuális víz kereskedelme számos más vízzel kapcsolatos kérdéskört érint, ezért szükséges ezen ügykör bevonása is egy komplex nemzetközi vízügyi viszonyrendszerbe. Jelenleg azonban a kérdéskör még mint kereskedelmi ügy tételezett, amely ügyben - jellegénél fogva - nem a vízgazdálkodási kérdések dominálnak. Egyszerü lenne a dolog (a nagy vízigényű termékek kereskedelme), ha mindez csak egy nemzetállam keretei között történne. Ekkor például egy plusz járulék bevezetésével, s így a vízigényes áru előállításának ökoszisztémára gyakorolt negatív hatásainak a termék árába való beépítésével arra lehetne ösztönözni a termelőket, előállítókat, hogy csökkentsék vagy szüntessék meg az áru ökoszisztémára gyakorolt kedvezőtlen hatásait (e kérdéskör e ponton nagyban összekapcsolódik a költségmegtérülés elvével is). Ám a globalizált gazdaságban egy ilyen intézkedés versenyképtelenné (azaz nehezen eladhatóvá) tehet egy árut... (ii) A virtuális vízkereskedelem első ránézésre jó lehetőséget kínálhat bőséges vízkészlettel rendelkező fejlődő országoknak, hogy növeljék gazdaságukat a vízigényes termékek exportjával. Sajnálatos módon azonban az ehhez szükséges versenyképes infrastruktúra kifejlesztése már eleve befektetéseket igényel, és számos fejlődő ország esetén inkább vízhi-

39 Érdekességképpen jegyezzük meg, hogy nemzetközi gazdasági kapcsolatok (de legalábbis a WTO) jogában is foglalkoznak a víz természeti erőforrás jellegével. A víz kimeríthetö természeti erőforrás jellege mellett érvel a GATT XX. cikke kapcsán: MosotI, Victor-VAPNEK, Jessica-VIDAR, Margret: Conceptions of Water. In: Aylward, Bruce et al (eds.): Law for water management: a guide to concepts and effective approaches. FAO Legislative Study 101. FAO, Rome, 2009, 330; továbbá MATSUOKA, Katsumi: Tradable water in GATT/WTO law: need for new legal frameworks?, http://www.awra.org/proceedings/dundee01/Documents/Matsuoka. pdf (2011. 08. 01.), 5; lásd továbbá: WT/DS58/R, 1998. május 15.; WT/DS58/AB/R, 1998. október 12.

40 SZILÁGYI (2013): i. m., 167-180.

41 World Water Assessment Programme (WWAP): Managing Water under Uncertainty and Risk (l. kötet), The United Nations World Water Development Report 4 (WWDR 4). UNESCO, Paris, 2012, 33-34.

42 Azt a jövőt építjük, amelyet szeretnénk, EEA Jelzések 2012. European Environmental Agency, 49.

43 WWAP: i. m., 2012, 33-34. 
ány van (mintsem bőség), amihez kapcsolódóan ezen országok lakossága inkább behozatalra szorul az élelmiszerböl (amit pedig nem vagy csak nehezen engedhet meg magának). (iii) A globálisan tapasztalható mezőgazdasági földszerzés, -felvásárlás növekedése (az ún. land-grabbing) szintén számos aggodalomra adhat okot; vagyis hogy bizonyos esetekben a földjeikben érintett országok és azok lakossága számára ez a folyamat aránytalan hátrányokkal járhat. Bár az kétségtelen, hogy számos befektető részéről a vízhiány az egyik fontos oka a nagymértékü földszerzésnek, a vizet tipikusan nem szokták explicit módon megemlíteni a nyilvánosságra került földügyletekben. Azon néhány esetben is, amikor félreérthetetlenül utalnak vízre, nem határozzák meg az engedélyezett vízkivétel mennyiségét. Mindez pedig érdekütközéshez vezethet, amely összeütközés feloldásában nem egyenlő esélylyel vesznek részt a vidéki szegények és a hatalommal, illetve a vízkivételhez jobb technikai eszközökkel rendelkező befektetők. Mindehhez államközi konfliktusok is párosulhatnak, különösen a nemzetközi vízgyüjtő területek esetén. A magunk részéröl mindezekre tekintettel érdemesnek tartanánk a virtuális vízkereskedelem viszonyrendszerében is újraelemezni a magyar földforgalmi törvényt (2012:CXXII. tv.), illetve a mezőgazdasági öntözés megújult szabályozási rendszerét. ${ }^{44}$ (iv) Az ENSZ végezetül felhívja a figyelmet a nemzetközi befektetési szerződések esetleges olyan hatásaira, amelyek érinthetik az adott nemzet vízgazdálkodását és közmüszabályozását. A globalizáció következményeként ugyanis gazdasági társaságok biztosítanak számos víziközmü-szolgáltatást, illetve ők rendelkeznek vízhasználati jogokkal. Az ő jogosítványaikat pedig olyan befektetővédelmi rendszerek (illetve konfliktuskezelési mechanizmusok) biztosítják, amelyek lehetőséget adnak arra, hogy egy külső szerv (például egy nemzetközi választottbíróság) döntsön a helyi ügyekben. Ezentúl a nemzetközi befektetési szerződések korlátozhatják a kormányok cselekvési lehetőségeit a közérdek érvényesítése terén is. Emiatt sok országnak elemeznie kellene ezen nemzetközi szerződések hatásait a fenntarthatóság, a hatékony vízgazdálkodás és víziközmü-szolgáltatások szabályozása terén is. ${ }^{45}$

c) Rátérve a víz mint áru kategóriára, érdemesnek tartjuk megemlíteni azt, hogy a víz egyúttal élelmiszer is lehet (kapcsolódó kategóriák még: emberi fogyasztásra szánt víz, ivóvíz), mely vonatkozásban számos jogi elöírást találhatunk ${ }^{46}$ különösen az élelmiszerlánc-szabályozás terén. A víz élelmiszer jellege kapcsán érdemesnek tartjuk vizsgálni az élelmiszerhez való jog bizonyos aspektusait, különös tekintettel annak viszonyát a vízhez való joghoz.

A víz mint szolgáltatás kategória kapcsán elsőként egy nagyon fontos megkülönböztetésre érdemes kitérnünk. Nevezetesen, hogy a kereskedelmi értelemben vett vízszolgáltatási kategórián túl tárgyalni kell a környezeti szolgáltatás kategóriáját is. A két kategória közötti különbségtétel volt az egyik hangsúlyos kérdése az Eu-

44 Az öntözés új szabályai kapcsán lásd SzILÁGYI János Ede: A mezőgazdasági öntözéssel összefüggő egyes jogi problémákról. Miskolci Jogi Szemle, 2015/1, 33-51.

45 A kérdéskör kapcsán lásd még Haller, Stella-Unterkircher, Carin (szerk.): Vízkészleteink kizsákmányolása. Global 2000, Bécs, 2011, 17-20.

46 SZILÁGYI (2013): i. m., 227-228. 
rópai Unió Bírósága (CJEU) előtt zajló ügynek, ${ }^{47}$ amelyben az Európai Unió Bizottsága és Németország - utóbbi oldalán beavatkozóként részt vett Magyarország ${ }^{48}$ is - a VKI költségmegtérülési elvének alkalmazásán vitáztak a vízszolgáltatások viszonylatában. A 2014. szeptember 11-én zárult ügy egyik lényeges kérdése tehát az volt, hogy mit is takar a VKI vízszolgáltatás fogalma, $s$ hogy azt kereskedelmi ${ }^{49}$ vagy környezeti ${ }^{50}$ értelemben kell-e alkalmazni. A vita tétje ugyanis az volt, hogy a költségmegtérülés elvét vajon az európai vízkivételek ${ }^{51}$ pusztán $21 \%$-ára (ezt az álláspontot erősíti a kereskedelmi értelmezés) vagy pedig $80 \%$-ára (ezt erősítette volna a környezeti értelmezés) kell-e alkalmazni. Meglátásunk szerint - amely álláspontunkat egy korábbi munkánkban ${ }^{52}$ fejtettük ki részleteiben - a CJEU nem foglal egyértelmü állást az értelmezési vita e részében, ${ }^{53}$ azonban az ítélet más részeiből arra a következtetésre lehet jutni, hogy a CJEU a VKI értelmezése kapcsán alapvetően a kereskedelmi megközelítést véli helytállónak. A VKI elemzését alapul véve magunk egyébiránt úgy látjuk, hogy a VKI vízszolgáltatás fogalmának leginkább a belső piaci (vagyis kereskedelmi) értelemben vett szolgáltatás fogalomértelmezés felel meg, míg a környezeti szolgáltatás koncepciója a költségmegtérülés elvének egyik költségtényezőjével, az ún. külső költségek vonatkozásában tünik fel és bír relevanciával.

A VKI a vízszolgáltatásokra vonatkozó költségmegtérülési elv taglalása kapcsán (9. cikk) kiemelten kezeli az ipari, a mezőgazdasági és a háztartási vízhasználatot. Ennek megfelelően a következőkben alapvetően ezen vízhasználatokra koncentrálva folytatjuk tovább elemzésünket.

Az ipari vízhasználat vonatkozásában egyrészt általánosságban utalnunk kell a virtuális vízkereskedelem kapcsán leírtakra, másrészt pedig érdemesnek tartjuk külön kiemelni az energiaszektor specialitásait. Az energiaszektor ugyanis számos

47 Lásd a korábban hivatkozott C-525/12. sz., Európai Bizottság kontra Németországi Szövetségi Köztársaság ügyet (ECLI:EU:C:2014:2202).

48 Beavatkozó beadványában Magyarország egyébiránt arra is felhívta a figyelmet, hogy a VKI „elfogadását megelőző jogalkotási munka során kifejezetten elvetették a Bizottság azon álláspontját, hogy a költségek megtérülésének elve valamennyi vízügyi tevékenységre kiterjedjen". C-525/12. sz., Európai Bizottság kontra Németországi Szövetségi Köztársaság ügy 2014. május 22-i fötanácsnoki indítványának 37. pontja (ECLI:EU:C:2014:449).

49 Ennek elsődleges jogszabályhelyei: EUMSZ 57. cikk, az Európai Parlament és a Tanács 2006/123/EK irányelvének 4. cikke.

50 Ennek elsődleges jogszabályhelye a 2004/35/EK európai parlamenti és tanácsi irányelv 2. cikkének 13. pontja. Fontos kihangsúlyoznunk, hogy az EU bizottsági vélemény szerint ez a környezeti szolgáltatás fogaIom nem esik egybe a ENSZ millenniumi ökoszisztéma-felmérésében meghatározott ökoszisztéma-szolgáltatások (ecosystem services) kifejezéssel, amely az embernek nyújtott olyan szolgáltatásokra vonatkozik, mint amilyen az édesvízellátás és a belvízi utak, amelyek feltételezik valamely emberi lény részvételét. Lásd a C-525/12. sz., Európai Bizottság kontra Németországi Szövetségi Köztársaság ügy 2014. május 22-i fötanácsnoki indítványának 32. pontját és annak 39. lábjegyzetét (ECLI:EU:C:2014:449).

51 C-525/12. sz., Európai Bizottság kontra Németországi Szövetségi Köztársaság ügy 2014. május 22-i fötanácsnoki indítványának 31. pontja és 37. lábjegyzete (ECLI:EU:C:2014:449).

52 SzILÁGYI János Ede: Az uniós Viz-keretirányelv költségmegtérülésének elve az Európai Bíróság esetjogának tükrében. Kézirat, megjelenés alatt.

53 Vö. ezzel szemben a C-525/12. sz., Európai Bizottság kontra Németországi Szövetségi Köztársaság ügy 2014. május 22-i fötanácsnoki indítványának 59-63., valamint 68-70. pontjaival (ECLI:EU:C:2014:449). 
szállal kapcsolódik a vízhasználathoz, ${ }^{54}$ és a magyar aktualitásokat tekintve is rendkívül szerteágazó joganyag alkalmazását igényli; lásd például a vízenergiával mint megújuló energiával összefüggő szabályokat, ${ }^{55}$ a termálenergia hasznosításával összefüggő problémakört ${ }^{56}$ vagy éppen az atomreaktoraink hütése kapcsán felvetett természetvédelmi vonatkozásokat.

A mezőgazdasági vízhasználat kapcsán Magyarországon nagy változások történtek, illetve vannak folyamatban, és ezekkel összefüggésben komoly jogi problémák megoldására is sort kellett keríteni. Mivel ennek részleteivel egy korábbi munkánkban $^{57}$ foglalkoztunk, ezért itt pusztán csak arra utalunk, hogy a kérdéskör rendezése kapcsán a jogalkotó fontosnak tartotta újrafogalmazni a (területi vízgazdálkodás ${ }^{58}$ jogi fogalmával összefüggésben álló, de azt nem kimerítö) mezőgazdasági célú vízgazdálkodás ${ }^{59}$ fogalmát, és egyúttal beiktatni a mezőgazdasági vízszolgáltatás ${ }^{60}$ fogalmát is, amely pedig magában foglalja a mezőgazdasági területek öntözését, ${ }^{61}$ a halastavak és egyéb mezőgazdasági vízhasználat vízellátását szolgáló, továbbá a mezőgazdasági vízszolgáltatási rendszerhez kapcsolódó, egyéb célú vízigények kielégítésére irányuló tevékenységeket.

A háztartási vízhasználaton magunk az emberi személyes szükségletek kielégítését célzó vízfelhasználást értjük. A közvetlen emberi vízfelhasználás kereskedelmi értelemben véve nem feltétlenül esik egybe a vízszolgáltatások kategóriájával (csak ismétlésképpen utalunk rá, hogy a C-525/12. sz. ügyben megnyilvánuló bizottsági álláspont szerinti környezeti vízszolgáltatás fogalom ezzel szemben kiterjedt az önellátási célú vízkivételre is ${ }^{62}$ ). A kérdéskör két lényegi vonatkozása az ivóvíz és a szanitáció kérdése (utóbbi kapcsán a magyar szakma szívesen látna valamilyen magyar kifejezést is).

E szabályozási csomópont egyik fontos leágazása a vízhez való jog ${ }^{63}$ kérdése. A vízhez való jog meghatározása mind fogalmi, mind tartalmi aspektusból számos variációval bír. Nem találkozhatunk egyetlen egységes koncepcióval. A magunk

${ }^{54}$ Az összefüggések vonatkozásában lásd SzLLÁGY (2013): i. m., 34, 156-158.

55 Lásd OLAjos István: A megújuló energiaforrások és a kapcsolt energiatermelés. In: Szilágyi János Ede (szerk.): Környezetjog. Novotni Kiadó, Miskolc, 2010, 172-180.

56 Ennek aktuális szabályozása kapcsán lásd SzILÁGYI (2014): i. m., 42-43.

57 Lásd SzILÁgyı (2014): i. m.

58 A vízi társulatokról szóló 2009. évi CXLIV. tv. 1. § 35. pont.

59 Vgtv. 1. m. 13. pont.

60 Vgtv. 1. m. 41. pont.

61 A mezőgazdasági öntözésre lásd: 147/2010. R 2. § 24. pont.

62 Lásd a C-525/12. sz., Európai Bizottság kontra Németországi Szövetségi Köztársaság ügy 2014. május 22-i fötanácsnoki indítványának 32. pontját és annak 39. lábjegyzetét, illetve vö. azt a főtanácsnoki indítvány 59-63. pontjaival (ECLI:EU:C:2014:449).

${ }^{63}$ Ennek magyar jogirodalma kapcsán lásd különösen Szappanyos Melinda: Víz és jog. Veszprémi Humán Tudományokért Alapítvány, Veszprém, 2013, 11-130; Greksza Veronika-Szabó Marcel (szerk.): i. m., 2-15 (Szabó), 34-48 (Bujdos-Fodor), 49-67 (Kardos KaponyI), 97-114 (KÉrI), 116-135 (Baillat-Schmitz), 136-154 (BuXhoeveden-Belényesi), 155-169 (PÁnovics), 170-179 (Szemesı), 180-193 (Szappanyos), 194-211 (GREKSZA); ANTALI Dániel Gábor: A kék bolygó kincse - A vízhez való jog szabályozása nemzetközi és nemzeti szinten. Jog-és Politikatudományi Folyóirat, 2011/4, 1-40; KARDos Gábor: A vízhez való jog. Acta Humana, 2004/1, 93-98; KECSKÉs Gábor: A vízhez való jog nemzetközi jogi koncepciója. Állam- és Jogtudomány, 2009/4, 569-598. 
részéröl a vízhez való jog elnevezést mint az egyes altípusok átfogó kategóriáját használjuk. ${ }^{64} \mathrm{Az}$ emberi jogok témaköréhez sorolt szabályozási csomópont kötelező érvényű normaként történő általános nemzetközi elfogadottsága is még várat magára. Magyarország esetében fontos feltenni azt a kérdést, hogy jelenlegi belső jogi szabályozásunk ismeri-e ezen kategóriát. Meglátásunk szerint a válasz egyértelműen igen. A 2012-töl hatályos magyar alkotmányban - megítélésünk szerint - elsődlegesen a XX. cikk foglalkozik a vízhez való joggal, mintegy a testi és lelki egészséghez való joggal kapcsolatban. Raisz Anikó értelmezése szerint a vízhez való jog Alaptörvényben meghatározott módozata, a 15. számú kommentárhoz, illetve a 64/292. számú ENSZ közgyülési határozathoz képest egy szükebb koncepciót takar. Ennek megfelelően a magyar meghatározás számos lehetőséget nem foglal magában; például a közegészségügyi szolgáltatásokat, az ivóvíz pénzügyi megengedhetőségének követelményét, az egyéb háztartási vízfelhasználás és a mezögazdasági vízfelhasználás körét. Mindezek ellenére, tekintettel arra, hogy a vízhez való jog nemzetközi közösségben való elfogadottsága még meglehetősen az elején tart, az új magyar alkotmány haladó szellemünek tekinthető. ${ }^{65}$ Nagyon fontosnak tartjuk mindezek mellett annak vizsgálatát is, hogy mennyiben érvényesül e jog a magyar jogrendszerben. ${ }^{66}$

E szabályozási csomópont víziközmü-szolgáltatáshoz kapcsolódó részei a vízjogi témakör egyik leggyakrabban kutatott területe a magyar jogtudományban. ${ }^{67} \mathrm{~A}$ témakör két meghatározó magyar vonatkozása egyrészt - a költségmegtérülés elvével szoros összefüggésben - a víz értékének meghatározása (avagy a víz ára), ${ }^{68}$ másrészt pedig a vízszektor és a közszféra-magánszféra szerepvállalása, amely utóbbi kérdéskörnek szintén több megközelítése vetődhet fel: a vízszektor libera-

${ }^{64}$ A szabályozási csomópont kifejtése kapcsán nagyban támaszkodhattunk Raisz Anikó munkájára: RAIsz Anikó: A vízhez való jog egyes aktuális kérdéseiröl. In: Csák Csilla (szerk.): Jogtudományi tanulmányok a fenntartható természeti eröforrások témakörében. Miskolci Egyetem, Miskolc, 2012, 151-159 [a továbbiakban: RAISz (2012)].

65 RAISz (2012): i. m., 156-157.

66 Ennek keretében tartjuk fontosnak például a Víz és Egészség Jegyzőkönyv (kihirdetéséről lásd a 213/2005. Korm. rendeletet) kapcsán kiadott nemzeti jelentéseinket, vagy éppen az alapvető jogok biztosának kapcsolódó tevékenységét.

67 A magyar jogirodalom kapcsán lásd különösen BELÉNYESI Pál: A vízszolgáltatások hatékonyságának javitása a Vízkeretirányelv egyes rendelkezései és a szennyezö fizet elvének tükrében. PhD-értekezés, Debreceni Egyetem, Debrecen, 2013; HEGEdüs József-TönKö Andrea: A víz- és csatornaszolgáltatás alternatív strukturális modelljei és ezek változási irányai. In: Horváth M. Tamás (szerk.): Külön utak, Dialóg Campus, Budapest-Pécs, 2014, 11-31; Pump Judit: A jog hatása a fenntartható közszolgáltatásra a hulladékgazdálkodás és a vízgazdálkodás területén. PhD-értekezés (kutatóhelyi vita verziója), Eötvös Loránd Tudományegyetem, Budapest, 2011.

68 BeLÉNYESI: i. m., 237-244. 
lizációja (deregularizációja) - privatizációja ${ }^{69}$ vagy éppen szorosabb szabályozása (regularizációja) - államosítása ${ }^{70}$, illetve (re)municipalizációja. ${ }^{71}$

\section{A víz mint káresemény, avagy védelem a víztöl}

A víz mint káresemény elnevezésủ koncepció más koncepciókhoz való viszonya kapcsán elmondható, hogy míg a víz mint környezeti elem vonatkozásában a víz volt az, amit óvni kíván a jogalkotó, addig itt éppen fordítva, vagyis a víz káros hatásaitól kívánjuk megóvni a társadalmat. A víz mint természeti erőforrás koncepció VKI-beli vonatkozásai (C-525/12. ügy) kapcsán pedig például az árvízvédelem tűnt fel úgy, mint egy esetleges vízszolgáltatási tevékenység. Fontosnak tartjuk rögzíteni, hogy adott szituációban érdemes megfontolni: vajon tényleg az-e a jelen és jövő generációk érdekeit szolgáló megoldás, ha a végletekig védekezünk a víz természetes folyamatai ellen? Nem lenne-e helyénvaló az árvízzel sújtott területek vonatkozásában megfontolni a természetközeli vízjárás részleges helyreállítását, és egy természethez közeli (táj)gazdálkodás folytatását. A vizek kártételei elleni védekezés során - a sokat hangoztatott integráció szellemében - fontos lenne, hogy az egyes káresemények (árvíz, belvíz, aszály) elleni védekezést összehangolják egymással, valamint a vízgazdálkodás más elemeivel, a területhasználattal és különösen a mezőgazdasággal (például az öntözés vonatkozásában); mindez nagyban összefügg a vízgazdálkodás vízvisszatartás irányába történő elmozdításával. A koncepció két kiemelt jogi relevanciával bíró területe a területi vízgazdálkodás korábban említett jogintézménye (összefüggésben a katasztrófavédelemmel), valamint az időjárási szélsőségek elleni harc jegyében felértékelődő mezőgazdasági kockázatkezelési rendszer. ${ }^{72}$

${ }^{69}$ A magyar jogirodalom kapcsán lásd különösen HoRvátH M. Tamás: Közszolgáltatás, magánszerveződés - privatizáció a településeken. Magyar Közigazgatás, 1997/4, 197; HoRvátH M. Tamás: Közszolgáltatás, magánszerveződés - privatizáció a településeken. Magyar Közigazgatás, 1997/5, 258. A privatizáció meghatározásán jelen tanulmány keretei között elfogadjuk Horváth $M$. Tamás utóbbi munkájában található meghatározást, amely szerint „közszolgáltatások terén privatizációnak nevezzük azt a folyamatot, amelynek során [a] a közjavak magánjószágokká válnak, illetve [b] a magánszektor a közigazgatás megbízásából lát el közfeladatot, vagy egyébként közösségi érdekeltségü feladatot végez".

70 A magyar jogirodalom kapcsán lásd különösen HoRvÁTH M. Tamás-PÉTERI Gábor: Nem folyik az többé viszsza - Az állam szerepének átalakulása a víziközmü-szolgáltatásban. In: Kiss Ferenc László-Nagy Csongor István-Valentiny Pál (szerk.): Verseny és szabályozás - 2012. MTA KRTK Közgazdaság-tudományi Intézet, Budapest, 2013, 177-200; SZILÁGYI (2013): i. m., 163-214.

71 Municipalizáción jelen tanulmány keretei között azt értjük, amikor (szükebb értelemben) helyi önkormányzat tulajdonába kerül a vízi közmü, vagy (mintegy tágabb értelemben) amikor a vízi közmű müködtetésében a helyi önkormányzati szerepvállalás aránya nő. A remunicipalizáción pedig azt a folyamatot értjük, amikor a helyi önkormányzat visszaszerzi a vízi közmű tulajdonjogát, avagy a müködtetése feletti rendelkezési jogot.

72 A rendszer jogszabályi alapja kapcsán lásd: a mezőgazdasági termelést érintő időjárási és más természeti kockázatok kezeléséről szóló 2011. évi CLXVIII. törvény, a mezőgazdasági biztositás dijához nyújtott támogatásról szóló 19/2014. (X. 29.) FM rendelet, a kárenyhítési hozzájárulás megfizetésével, valamint a kárenyhitó juttatás igénybevételével kapcsolatos egyes kérdésekröl szóló 27/2014. (XI. 25.) FM rendelet. 


\title{
6. Összegzés
}

A tanulmányban a föbb vízjogi szabályozási csomópontok közötti viszony rendezését tüztük ki célul. Megítélésünk szerint ez a viszony rendkívül komplex, több síkon is megközelíthető. Jelen munkában egy lehetséges - alapvetően a magyar társadalom aktuális problémáira fókuszáló - megközelítés mentén kíséreltük meg e viszony feltárását, abban a reményben, hogy mindez lehetőséget teremt más megközelítési módok könnyebb alkalmazására is.

\begin{abstract}
The present article concentrates on the so-called water law concepts. As regards water law concepts, the article especially deals with the challenges of the Hungarian water management. The article has five main chapters. In the first chapter, the author focuses on the basis of the water law concepts, namely on natural, social and engineering sciences, furthermore, the author also determines the legal instruments which are able to provide proper links among the different water law concepts. The further four chapters analyse the water law concepts one by one; i.e. (a) ruling over waters, (b) water as an environmental component, (c) water as the subject of commercial deals (good or service), (d) water as cause of damage a.k.a. defence against water.
\end{abstract}

